\section{Delayed Effect of Thymectomy in Adult Life on Immunological Competence}

Neonatal thymectomy leads to the rapid development of lymphoid organ atrophy and well-characterized immunological deficiencies ${ }^{1-3}$, but thymectomy performed in adult life leads only to the slow development of a moderate degree of lymphoid atrophy ${ }^{4}$ with no loss of immunological competence when the animals are tested immediately after operation ${ }^{5,6}$. However, adult thymectomy combined with whole-body irradiation does lead to immunological deficiencies of the same gentral nature as those following neonatal thymectomy? ${ }^{\text {? }}$ Recent investigations have shown that continuous repopulation of normal haemopoietic organs occurs in normal life ${ }^{8,9}$. This suggests that whole-body irradiation by causing cell damage and repopulation in haemopoietic organs may merely accelerate a process which occurs continually throughout life, albeit at a much slower rate. These considerations prompted a re-examination of the longterm effects of adult thymectomy on immunological competence.

Six-week-old mice of the long-lived $(A K R \times C 57 B L) F$ strain were thymectomized or sham-operated and challenged 1 week, 11 months or 18 months after operation with intraperitoneal sheep red cells.

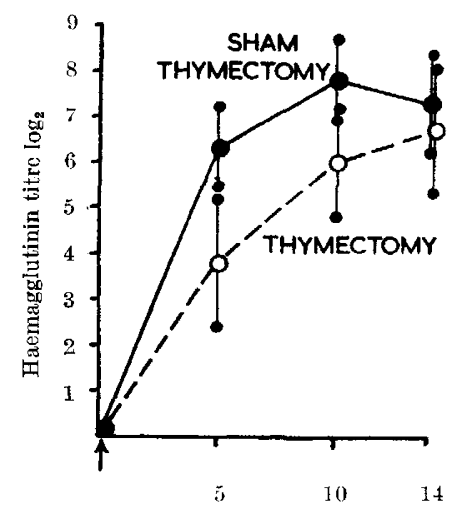

Days after immunization

Fig. 1. Haemaggiutinin titres in $(A K R \times C 57 B L) F_{1}$ mice tested 11 months after thymectomy or sham-operation at six weeks of age. No. of mice: thymectomy 23 , sham-thymectomy 31 . Bars represent standard

The present results re-emphasize that the thymus has a continuing influence on immunological responsiveness throughout adult life, but do not indicate the processes

Table 1. Primary haemaggletinin Resyonse of $(A B R \times C 5 T B L) F_{\imath}$ Mice to Sheep Red blood Chlls

\begin{tabular}{|c|c|c|c|c|c|c|c|c|c|c|c|c|c|}
\hline \multirow{2}{*}{ Type of mouse } & \multirow{2}{*}{$\begin{array}{c}\text { No. of } \\
\text { animals }\end{array}$} & \multicolumn{12}{|c|}{ Haemagglutinin titres $\left(\log _{2}\right)$} \\
\hline & & 0 & 1 & 2 & 3 & 4 & 5 & 6 & 7 & 8 & 9 & 10 & 11 \\
\hline $\begin{array}{l}\text { Normal } 2 \text { months old. No antigen } \\
\text { Normal } 18-20 \text { months old. No antigen } \\
\text { Thymectomy + antigen. 1 week after operation } \\
\text { Sham-thymectomy + antigen. 1 week after operation } \\
\text { Thymectomy + antigen. } 11 \text { months after operation } \\
\text { Sham-thymectomy + antigen. } 11 \text { months after opera- } \\
\text { tion } \\
\text { Thymectomy + antigen. } 18 \text { months after operation } \\
\text { Sham-thymectomy + antigen. } 18 \text { months after opera- } \\
\text { tion }\end{array}$ & $\begin{array}{l}14 \\
18 \\
13 \\
14 \\
23 \\
31 \\
13 \\
48\end{array}$ & $\begin{array}{l}12 \\
18\end{array}$ & 1 & 1 & 4 & 3 & $\begin{array}{l}2 \\
4\end{array}$ & $\begin{array}{l}6 \\
1\end{array}$ & $\begin{array}{l}10 \\
13\end{array}$ & $\begin{array}{r}5 \\
5 \\
1 \\
13 \\
2 \\
12\end{array}$ & $\begin{array}{l}3 \\
2 \\
3\end{array}$ & $\begin{array}{l}1 \\
3\end{array}$ & 1 \\
\hline
\end{tabular}

Immunizing dose: $0.2 \mathrm{ml}$, of 20 per cent R.B.C. i.p. Sera titrated on day 10 following immunization.

Haemagglutinin titres in mice challenged immediately after thymectomy did not differ from those in control mice (Table 1). However, in mice tested 11 months after thymectomy, some lower titres were found, particularly in the early (19S) phase of the response (Fig. 1). In mice tested 18 months after operation, approximately half the thymectomized mice produced no detectable haemagglutinins (Table 1), the remainder producing titres within the control range. The titres in the thymectomized mice challenged 18 months after operation corresponded almost exactly with those observed by Miller ${ }^{7}$ in young adult mice subjected to thymectomy and 350-r. wholebody irradiation. The spleen is the major source of haemagglutinin-production (Metcalf, unpublished results) and in the immunized thymectomized mice challenged 18 months after operation, a general disorganization of the structure of the spleen lymphoid nodules was observed with an obvious decrease in the numbers of germinal centres and small lymphocytes and a diminished number of pyroninophilic mitotic cells.

The observations recorded here suggest that simple thymectomy performed on adult mice does lead to demonstrable immunological deficiencies in at least some mice, provided sufficient time is allowed to elapse before the animals are tested. The present results are only preliminary and need confirmation with other mouso strains and other antigens. The irregular nature of the loss of immunological competence in individual mice following thymectomy, suggests a deletion or loss of responsiveness in some mice of clones of cells capable of responding to the antigen used, this loss apparently being on a random basis and time dependent. involved. The thymus is known to produce the humoral factor L.S.F. throughout $\operatorname{life}^{10}$ and a humoral influence of the thymus has been shown to be necessary for the full responsiveness of competent cells following antigenic stimulation ${ }^{11,12}$. Since there is continuous spleen and lymph node cell repopulation throughout life, the thymus could also serve as a production site for immunologically competent cells, continually reseeding the peripheral organs.

This work was supported by the Carden Fellowship Fund of the Anti-Cancer Couneil of Victoria.

\section{Donald Metcalf}

Cancer Research Laboratory,

Walter and Eliza Hall Institute,

Post Office Royal Melbourne Hospital, Victoria, Australia.

${ }^{1}$ Miller, J. F. A. P., Lancet, ii, 748 (1961).

2 Miller, J. F. A. P., Science, 144, 1544 (1964).

Martinez, C., Kersey, J., Papermaster, B. W., and Good, R. A., Proc. Soc. Exp. Biol., 109, 193 (1962).

${ }^{4}$ Metcalf, D., Brit. J. Haematol., 6, 324 (1960).

${ }^{5}$ Fichtelius, K. E., Laurell, G., and Philipsson, I., Acta Puthol. Microbiol. scand., 51, 81 (1961).

- MacLean, L. D., Zak, S. J., Varco, R. L., and Good, R. A., Transpl. Bull., 4.21 (1957).

'Miller, J. F. A. P., Nature, 195, 1318 (1962). Miller, J. F. A. P., Doak, S. M. A., and Cross, A. M., Proc. Soc. Exp. Biol., 112, 785 (1963).

${ }^{8}$ Harris, J. E., Barnes, D. W. H., Ford, C. E., and Evans, E. P., Nature, 201, 884 (1964).

Metcalf, D., and Wakonig-Vaartaja, R., Proc. Soc. Exp. Biol., 115, 731 (1964). Metcalf, D., and Wakonig-Vaartaja, P., Lancet, i, 1012 (1964)

${ }^{10}$ Metcalf, D., Brit. J. Cancer, 10, 442 (1956).

11 Osoba, D., and Miller, J. F. A. P., Nature, 199, 653 (1963). 12 Levey, R. H., Trainin, N., and Law, I. W., J. Nat. Cancer Inst., 31, 199 